\title{
Phylogenetic inferences of Nepenthes species in Peninsular Malaysia revealed by chloroplast (trnL intron) and nuclear (ITS) DNA sequences
}

\author{
Hamidun Bunawan ${ }^{1}$, Choong Chee Yen², Salmah Yaakop ${ }^{2}$ and Normah Mohd Noor ${ }^{\text {* }}$
}

\begin{abstract}
Background: The chloroplastic trnL intron and the nuclear internal transcribed spacer (ITS) region were sequenced for 11 Nepenthes species recorded in Peninsular Malaysia to examine their phylogenetic relationship and to evaluate the usage of trnL intron and ITS sequences for phylogenetic reconstruction of this genus.

Results: Phylogeny reconstruction was carried out using neighbor-joining, maximum parsimony and Bayesian analyses. All the trees revealed two major clusters, a lowland group consisting of N. ampullaria, N. mirabilis, N. gracilis and N. rafflesiana, and another containing both intermediately distributed species ( $N$. albomarginata and $N$. benstonei) and four highland species (N. sanguinea, N. macfarlanei, N. ramispina and N. alba).

Conclusions: The trnL intron and ITS sequences proved to provide phylogenetic informative characters for deriving a phylogeny of Nepenthes species in Peninsular Malaysia. To our knowledge, this is the first molecular phylogenetic study of Nepenthes species occurring along an altitudinal gradient in Peninsular Malaysia.
\end{abstract}

Keywords: ITS, Nepenthes, Peninsular Malaysia, Pitcher plant

\section{Background}

Seven genera of pitcher plants namely Cephalotus, Heliamphora, Darlingtonia, Brocchinia, Nepenthes, Sarracenia and Catopsis. Pitcher plants have a worldwide distribution [1]. Nepenthes is the largest genus belonging to the family Nepenthaceae and consists of 120 species and five incompletely described taxa in seven geographical groupings: Nepenthes of Peninsular Malaysia and Indochina, Nepenthes of Borneo, Nepenthes of Sulawesi, Nepenthes of Sumatra and Java, Nepenthes of the Philippines, Nepenthes of New Guinea and Maluku Islands, and lastly Nepenthes of the Outlying Areas [1]. The endemic species of Nepenthes occur throughout Southeast Asia, particularly in the Sunda region, which includes Borneo,

*Correspondence: normah@ukm.edu.my

1 Institute of Systems Biology, Universiti Kebangsaan Malaysia (UKM),

43600 Bangi, Selangor, Malaysia

Full list of author information is available at the end of the article
Sumatra, the Malay Peninsula, Java and some of the southern islands of the Philippines [2].

The Nepenthes flora in Peninsular Malaysia is relatively poor with only 11 species presently recorded ( $N$. alba Ridl., N. albomarginata T. Lobb ex Lindl., N. gracillima Ridl., $N$. ampullaria Jack, $N$. benstonei C. Clarke, N. gracilis Korth., N. macfarlanei Hemsl., N. rafflesiana Jack, N. mirabilis (Lour.), Druce, N. ramispina Ridl. and $N$. sanguinea Lindl.). In comparison, there are 36 species recognized in Borneo, representing the greatest diversity of Nepenthes species in Southeast Asia [1,3]. Clarke [2] reported only ten species of Nepenthes in Peninsular Malaysia, classifying $N$. alba as a heterotypic synonym of $N$. gracillima. Four of these species are restricted to montane habitats (N. macfarlanei, N. gracillima, N. sanguinea, $N$. ramispina), two species are found mainly on low hills (N. albomarginata and $N$. benstonei) and another four are lowland species (N. ampullaria, $N$. gracilis, $N$. mirabilis 
and $N$. rafflesiana). McPherson [1] described both $N$. alba and N. gracillima as distinct species.

The taxonomy of Nepenthes is based primarily on morphology (shape, color, size and ornamentation) [1-6]. Jebb and Cheek [7] recognized a single species, N. vieillardii, in New Caledonia into a single species, even though several species were recognized based on morphological variation. Kurata et al. [8] clarified the morphological diversity and verified the species classification of $N$. vieillardii, and they tentatively supported the taxonomic classification based on the pitcher morphology by Jebb and Cheek [7]. The current classification of Nepenthes in Peninsular Malaysia is also based on morphological characteristics, with distinct differences apparent between species found at high, intermediate and low altitudes.

Previous molecular phylogenetic studies of Nepenthes based on chloroplast (trnK intron and matK gene) and nuclear (PRT1 and a translocated copy of trnK) sequences have provided a well-supported phylogeny of many species [9-11]. Using the plastid trnK intron in phylogenetic reconstruction, the three lineages can be separated according to habitat [9]. The first lineage included all species found in Sumatra, the Malay Peninsula and the Southeast mainland; the second lineage consisted of the species from Sulawesi, Borneo and the Philippines; and the third lineage comprised Nepenthes from New Guinea and Sulawesi $[9,11]$. Meimberg and Heubl [11] also suggested that biogeographic "outlier species" occurring in Seychelles (N. pervillei Blume.), Sri Lanka ( $N$. distillatoria L.), Madagascar ( $N$. madagascarensis Poir. and N. masoalensis Schmid-Hollinger) and
India (N. khasiana Hook. F.) are related to the three lineages consisting of all taxa from the Indo-Malay region.

Apart from molecular phylogenetic studies of Nepenthes using nuclear PRT and plastid mat K DNA sequences [9-11], there has been little development in the molecular systematics of Nepenthes. We report here the potential of the plastid trnL intron and nuclear ITS DNA sequences for the phylogenetic inference of Nepenthes in Malaysia. We also report here the phylogeographics of the Nepenthes species found in Peninsular Malaysia based on the DNA sequence data.

\section{Methods}

\section{Sample collection}

All the plant materials were collected from 11 sites (one individual from each of these localities) in Peninsular Malaysia, which covered nearly the complete natural range of the species except for $N$. gracillima Ridl (Table 1). Herbarium specimens were identified by Ruzi Rahman and deposited at the Universiti Kebangsaan Malaysia Herbarium (UKMB), Universiti Kebangsaan Malaysia.

\section{Molecular procedures}

DNeasy Plant Mini Kit (Qiagen, Germany) was used in extraction of total genomic DNA from fresh leaf tissue. The plastid $t r n \mathrm{~L}$ intron and the nuclear internal transcribed spacer (ITS) region consisting of ITS1, ITS2 and the 5.8S were PCR amplified. The amplification of the $\operatorname{trn} \mathrm{L}$ intron was done using primers c (5'-CGA AAT CGG TAG ACG CTA CG-3') and d (5'-GGG GAT AGA GGG ACT TGA AC-3') [12], and the amplification of the

Table 1 Sample location of Nepenthes species in Peninsular Malaysia and the outgroup species (Sarracenia flava)

\begin{tabular}{|c|c|c|c|c|c|}
\hline Name & Accessions & State & Altitude (m) & $\begin{array}{l}\text { GenBank (trnL } \\
\text { intron) }\end{array}$ & $\begin{array}{l}\text { GenBank } \\
\text { (ITS) }\end{array}$ \\
\hline N. ampullaria & INBIOSIS-N:AMP-2011 & Johor-Ulu Tiram-Mersing & $100-150$ & JX042566 & JX042554 \\
\hline N. gracilis & INBIOSIS-N:GRA-2011 & $\begin{array}{l}\text { Selangor-Bukit Putri-UKM } \\
\text { Bangi }\end{array}$ & $100-150$ & $J X 042567$ & JX042555 \\
\hline N. mirabilis & INBIOSIS-N:MIR-2011 & Selangor-Rawang/Batu Arang & $50-100$ & $J X 042568$ & JX042556 \\
\hline N. rafflesiana var. elongata & INBIOSIS-N:RAF-E-2011 & Johor-Ulu Tiram-Mersing & $150-300$ & $J \times 042569$ & JX042557 \\
\hline N. rafflesiana var. nivea & INBIOSIS-N:RAF-N-2011 & Johor-Ulu Tiram-Mersing & $150-300$ & JX042570 & JX042558 \\
\hline N. albomarginata & INBIOSIS-N:ALBO-2011 & Pahang-Cameron Highland & $600-1300$ & $J X 042571$ & $J X 042559$ \\
\hline N. benstonei & INBIOSIS-N:BEN-2011 & Kelantan-Bukit Bakar & $600-1000$ & JX042572 & $J X 042560$ \\
\hline N. sanguinea & INBIOSIS-N:SAN-2011 & Pahang-Cameron Highland & $1000-1500$ & JX042573 & $J X 042561$ \\
\hline N. macfarlanei & INBIOSIS-N:MAC-2011 & Kelantan-Cameron Highland & $800-1800$ & $J \times 042574$ & $J X 042562$ \\
\hline N. ramispina & INBIOSIS-N:RAM-2011 & Pahang-Cameron Highland & $600-1700$ & $J \times 042575$ & $J X 042563$ \\
\hline N. alba & INBIOSIS-N:ALBA-2011 & Pahang-Cameron Highland & $800-1800$ & JX042576 & $J X 042564$ \\
\hline Sarracenia flava & INBIOSIS-S:FLAVA-2011 & Selangor & $\begin{array}{l}300 \text { (Sarracenia originated from } \\
\text { North America-grown in } \\
\text { Selangor, lowland condition) }\end{array}$ & JX042577 & $J X 042565$ \\
\hline
\end{tabular}


Table 2 Pairwise distances of Nepenthes species generated from the combined trnL intron and ITS sequences based on uncorrected "p" model

\begin{tabular}{|c|c|c|c|c|c|c|c|c|c|c|c|c|}
\hline & 1 & 2 & 3 & 4 & 5 & 6 & 7 & 8 & 9 & 10 & 11 & 12 \\
\hline N. gracilis & - & & & & & & & & & & & \\
\hline N. rafflesiana var. elongata & 0.00405 & - & & & & & & & & & & \\
\hline N. ampullaria & 0.02427 & 0.02346 & - & & & & & & & & & \\
\hline N. mirabilis & 0.00488 & 0.00569 & 0.02522 & - & & & & & & & & \\
\hline N. rafflesiana var. nivea & 0.00405 & 0.00000 & 0.02346 & 0.00569 & - & & & & & & & \\
\hline N. albomarginata & 0.03078 & 0.02673 & 0.02876 & 0.03169 & 0.02673 & - & & & & & & \\
\hline N. benstonei & 0.03079 & 0.02673 & 0.02796 & 0.0317 & 0.02673 & 0.00238 & - & & & & & \\
\hline N. sanguinea & 0.03324 & 0.02919 & 0.03119 & 0.03415 & 0.02919 & 0.00318 & 0.00477 & - & & & & \\
\hline N. macfarlanei & 0.03243 & 0.02837 & 0.03038 & 0.03333 & 0.02837 & 0.00159 & 0.00397 & 0.00158 & - & & & \\
\hline N. ramispina & 0.03324 & 0.02919 & 0.03119 & 0.03415 & 0.02919 & 0.00238 & 0.00477 & 0.00237 & 0.00079 & - & & \\
\hline N. alba & 0.03159 & 0.02753 & 0.02955 & 0.03249 & 0.02753 & 0.00079 & 0.00317 & 0.00238 & 0.00079 & 0.00159 & - & \\
\hline Sarracenia flava & 0.2265 & 0.22316 & 0.22292 & 0.22296 & 0.22316 & 0.21805 & 0.21710 & 0.2185 & 0.21783 & 0.21783 & 0.21721 & - \\
\hline
\end{tabular}

ITS region was done using primers P17F (5'-CTA CCG ATT GAA TGG TCC GGT GAA-3') and 26S-82R (5'TCC CGG TTC GCT CGC CGT TAC TA-3') [13]. A $100 \mu \mathrm{L}$ PCR reaction was used in target gene amplification and consisted of the following components: $55 \mu \mathrm{L}$ $\mathrm{dH}_{2} \mathrm{O}, 20 \mu \mathrm{L} 10 \times$ buffer, $10 \mu \mathrm{L}$ of $25 \mathrm{mM} \mathrm{MgCl}_{2}, 2.0 \mu \mathrm{L}$ of $20 \mathrm{mM}$ dNTPs, $1.0 \mu \mathrm{L}$ each forward and reverse primers, $100 \mathrm{mM}, 1.0 \mu \mathrm{L}$ of Taq DNA polymerase (Promega) and $5 \mu \mathrm{L}$ genomic DNA (20 ng/uL). The PCR was carried out in thermocycler (Applied Biosystem, USA) under the following cycling conditions: preliminary denaturation at $95{ }^{\circ} \mathrm{C}$ for $2 \mathrm{~min}$; 35 cycles at $95{ }^{\circ} \mathrm{C}$ for $1 \mathrm{~min}, 45 / 66{ }^{\circ} \mathrm{C}$ for $1 \mathrm{~min}$, and $72{ }^{\circ} \mathrm{C}$ for $1 \mathrm{~min}$; final elongation at $72{ }^{\circ} \mathrm{C}$ for $5 \mathrm{~min}$. The resultant PCR products were cleaned with PureLink $^{\mathrm{TM}}$ PCR Purification Kit (Invitrogen) according to the manufacturer's protocol.

ABI Prism Dye Terminator Cycle Sequencing Ready Reaction kit and ABI PRISM 3100 Genetic Analyzer (Perkin-Elmer, Foster City, CA) was used in DNA sequencing, following the manufacturer's instructions. Direct sequencing was applied on both DNA regions in forward and reverse directions. The sequencing primers for the trnL intron were the same as the PCR primers. Primers P16F (5'-TCA CTG AAC CTT ATC ATT TAG AGG-3') and P25R (5'-GGG TAG TCC CGC CTG ACC TG-3') [13] were used to sequence the ITS region.

\section{Sequence analysis}

ClustalX Multiple Sequence Alignment programme was used to align DNA sequences using the default settings. Sarracenia flava was designated as the outgroup in the phylogenetic analyses. The DNA sequences of the ITS region and trnL intron were combined in phylogenetic analyses. The evolutionary history was analyzed by neighbor-joining (NJ) and maximum parsimony (MP) methods using PAUP* 4.0b10 [14]. All positions containing gaps and missing data were removed from the dataset using the 'complete deletion' option. The pairwise distances generated using the uncorrected "p" model were used to construct the NJ tree. For the MP analysis, the cladograms were constructed utilizing unordered parsimony with equal weight. A heuristic search was conducted with the tree bisection-reconnection (TBR) branch swapping algorithm, random stepwise addition and 'Mul-Trees' option set on all the characters were weighted equally. The internal branch supports for the NJ and MP trees were assessed with Bootstrap analyses using 500 replicates. Bayesian inferences were carried out [15, 16] using MrBayes 3.12 [17]. The general reversible model with Gamma distributed rate heterogeneity $(\mathrm{GTR}+\mathrm{G})$ was selected by AIC using MrModelTest version 2.2 [18]. Two simultaneous metropolis-coupled Monte-Carlo Markov chains for $>1,000,000$ generations, a sample frequency of 100 generations and average standard deviation of split frequencies 0.009311 was used in Bayesian inference.

\section{Results}

The PCR amplification and subsequent sequencing produced the ITS and $\operatorname{trn} \mathrm{L}$ intron ITS fragments with size ranges of 555-559 and 673-705 bp, respectively. A total of 1311 characters were involved in the phylogenetic analyses of which 1012 were constant and 42 were parsimony-informative, while 257 variable characters were parsimony-uninformative. The pairwise genetic distances among the Nepenthes taxa ranged from 0 to 0.0342 (Table 2). The analyses of the combined trnL and ITS sequence data produced the NJ, MP and Bayesian trees with same topology. The NJ tree is shown in Fig. 1a. The MP analysis produced two most parsimonious trees with 
a tree length of 327 steps, CI $=0.9755$ and $\mathrm{RI}=0.9424$. One of the parsimonious trees was similar to the topology of the Bayesian inference tree (Fig. 1b). The bootstrap values obtained from the MP analysis are shown above the branches.

All the trees indicated the formation of two major genetic lineages: (1) Clade A (N. albomarginata, N. benstonei, $N$. sanguinea, N. macfarlanei, N. ramispina and $N$. alba) and (2) Clade B (N. ampullaria, N. mirabilis, $N$. rafflesiana and $N$. gracilis). These two major clades were supported by high bootstrap values and good posterior probability values (Fig. 1).

\section{Discussion}

According to Clarke [2], only ten species of Nepenthes are presently recognized in Peninsular Malaysia on the basis of morphology. Four of these species are confined to montane habitats, two are found primarily on low hills and the remainders are lowland species that are common throughout the Sunda region. Based the combined trnL and ITS data, the lowland Nepenthes taxa in Peninsular Malaysia ( $N$. ampullaria, N. rafflesiana, N. mirabilis and $N$. gracilis) clustered together to form a clade. On the other hand, the two Nepenthes species found on the low hills ( $N$. albomarginata and $N$. benstonei) and

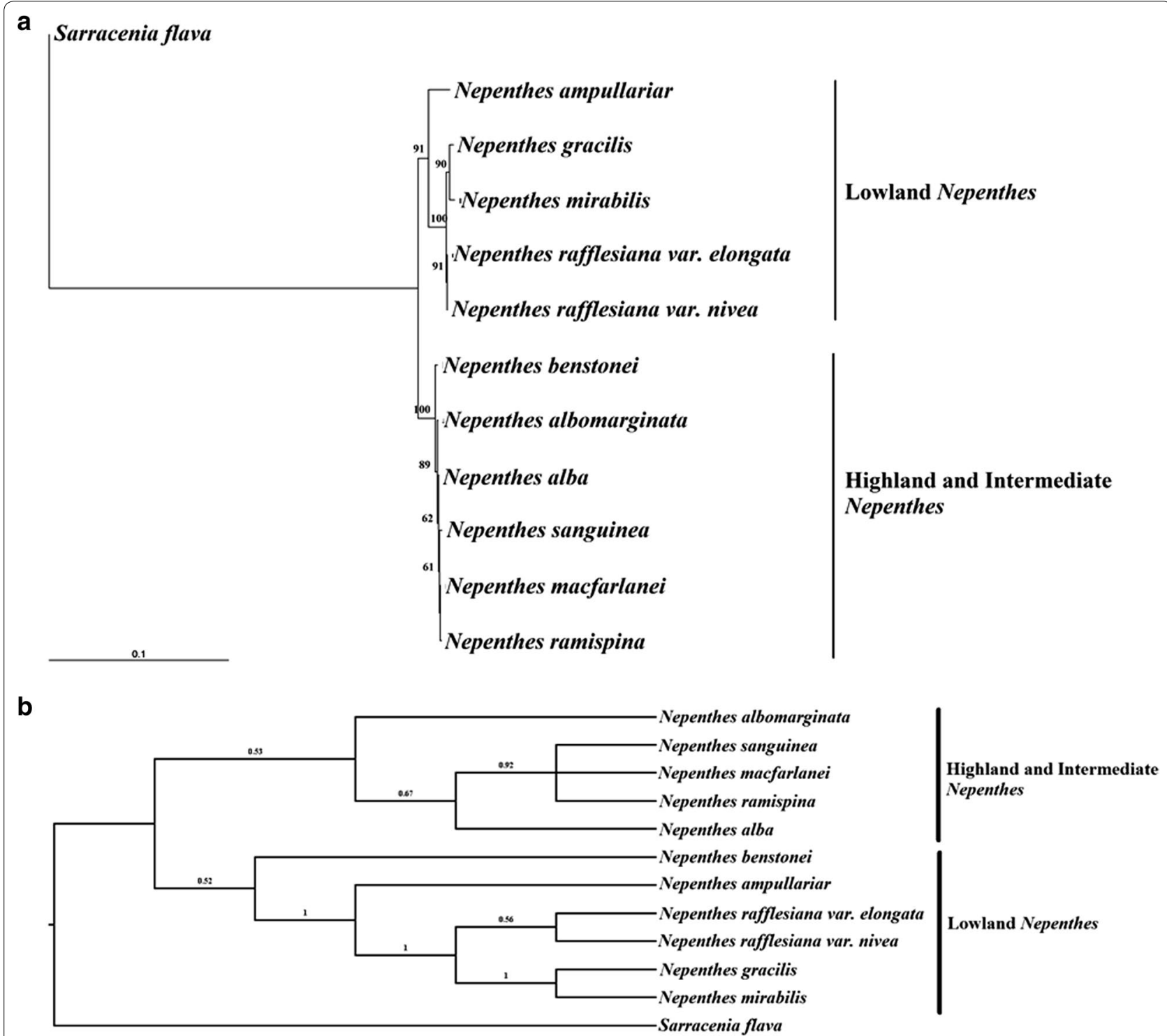

Fig. 1 a Neighbor-joining tree generated based on the combined trnL and ITS sequence data with yellow pitcher plant (Sarracenia flava) as outgroup, a carnivorous plant native to the New World. The numbers above the branches represent the bootstrap percentage. b Majority-rule consensus tree resulted from the Bayesian analysis of $t r n$ L and ITS sequence data. Numbers at below branches are posterior probabilities. The bootstrap values from the MP analysis are shown above the branches 
four highland species ( $N$. sanguine, $N$. macfarlanei, $N$. ramispina and $N$. alba) formed another clade. Therefore, this format of clustering corresponds to the altitudinal features of the natural growing habitats of Nepenthes in Peninsular Malaysia, suggesting differences in altitudinal growing environments probably played an important role in driving species radiation in the genus [19].

The four lowland Nepenthes species ( $N$. ampullaria, $N$. rafflesiana, $N$. mirabilis and $N$. gracilis) that occur in Peninsular Malaysia are the same species that form the lowland suite in Sumatra. Two species are primarily found at intermediate altitudes $-N$. albomarginata and $N$. benstonei in both Malaysia and Sumatra. Of the four highland species, two (N. sanguinea and $N$. macfarlanei) have relatively wide distributions, whereas the other two $(N$. ramispina and $N$. gracillima) are more restricted. $N$. albomarginata is sister to one of the major clades, whereas $N$. benstonei is basal to this entire group of taxa (Fig. 1). This may imply that the highland species have most likely evolved from the lowland species with the transitional form of intermediate altitude species. Long term isolation of each population and limited seed flow, demonstrated in Nepenthes vieillardii of New Caledonia [20], might partly explain the speciation of highland Nepenthes species of Peninsular Malaysia. Climate may also play a role in the speciation of Nepenthes, with changes in vegetation, soil type and nutrient availability permitting a range of distinct ecological niches for Nepenthes to exploit.

Phylogenetic relationships in several carnivorous genera have been inferred using ITS sequences. Use of nrITS2 and nrITS1 in phylogeny reconstruction of 29 species of Pinguicula showed that the molecular phylogeny was congruent with the morphological classification [21].

\section{Conclusions}

The trnL intron and ITS sequence data utilised in this work provided informative characters for the molecular phylogenetic inference of Nepenthes species in Peninsular Malaysia. The Nepenthes of Peninsular Malaysia formed two major clusters according to altitudinal distribution. It is reasonable to assume that the highland species have evolved from the lowland species. To our knowledge, this is the first attempt of applying the ITS and $\operatorname{trn} \mathrm{L}$ intron sequence data as potential markers for Nepenthes species in Peninsular Malaysia. Worldwide, there are over 120 described species of Nepenthes and future work could consider the relationship between these species and those found in Peninsular Malaysia.

\section{Abbreviations}

ITS: internal transcribed spacer; UKMB: Universiti Kebangsaan Malaysia Herbarium; NJ: neighbor-joining; MP: maximum parsimony.

\section{Authors' contributions}

HB, NMN: Study conception and design; HB, NMN, CYC, SY: Acquisition of data; HB, CYC, SY: Analysis and interpretation of data; HB: Drafting the manuscript; All authors read and approved the final manuscript.

\section{Author details}

${ }^{1}$ Institute of Systems Biology, Universiti Kebangsaan Malaysia (UKM), 43600 Bangi, Selangor, Malaysia. ${ }^{2}$ School of Environmental and Natural Resource Sciences, Faculty of Science and Technology, Universiti Kebangsaan Malaysia (UKM), 43600 Bangi, Selangor, Malaysia.

\section{Acknowledgements}

We would like to thank Mr. Fauzi and Mr. Saad for their help in collecting the plants.

\section{Competing interests}

The authors declare that they have no competing interests.

\section{Availability of data}

All the sequences used in this study have been deposited in the GenBank (https://www.ncbi.nlm.nih.gov/genbank/). JX042566; JX042567; JX042568; JX042569; JX042570; JX042571; JX042572; JX042573; JX042574; JX042575; JX042576; JX042577; JX042554; JX042555; JX042556; JX042557; JX042558; JX042559; JX042560; JX042561; JX042562; JX042563; JX042564; JX042565.

\section{Ethics approval and consent to participate}

According to the National Policy on Biological Diversity 2016-2025 and Forestry Act 1993 (Malaysia), no approvals or permits were required for the study.

\section{Funding}

This research was funded by a grant from the Ministry of Higher Education, Malaysia (UKM-RB-06-FRGS0259-2010). This funding source had no role in the design of the study and collection, analysis, and interpretation of data and in writing the manuscript.

Received: 13 June 2016 Accepted: 9 January 2017

Published online: 26 January 2017

\section{References}

1. McPherson SR. Pitcher Plants of the Old World 2 volumes. Poole: Redfern Natural History Productions; 2009

2. Clarke CM. Nepenthes of Sumatra and Peninsular Malaysia. Kota Kinabalu: Natural History Publications (Borneo); 2001.

3. Clarke CM. Nepenthes of Borneo. Vic Carniv Plant Soc J. 2002:65:19.

4. Phillipps A, Lamb A. Pitcher-plants of borneo. Kota Kinabalu: Natural History Publications (Borneo); 1996.

5. Cheek MR, Jebb MHP. Nepenthaceae. Flora Males. 2001;15:1-157.

6. Danser BH. The Nepenthaceae of the Netherlands Indies. Kota Kinabalu: Natural History Publications (Borneo); 2006.

7. Jebb MHP, Cheek MR. A skeletal revision of Nepenthes (Nepenthaceae). Blumea. 1997:42(1):1-106.

8. Kurata K, Jaffré T, Setoguchi H. Variation of pitcher morphology within Nepenthes vieillardii Hook.f. (Nepenthaceae) in New Caledonia. Acta Phytotaxon Geobot. 2004;55:181-97.

9. Meimberg H, Wistuba A, Dittrich P, Heubl G. Molecular phylogeny of Nepenthaceae based on cladistic analysis of plastid trnK intron sequence data. Plant Biol. 2001:3:164-75.

10. Meimberg H, Thalhammer S, Brachmann A, Heubl G. Comparative analysis of a translocated copy of the trnK intron in the carnivorous genus Nepenthes (Nepenthaceae). Mol Phylogenet Evol. 2006;39:478-90.

11. Meimberg H, Heubl G. Introduction of a nuclear marker for phylogenetic analysis of Nepenthaceae. Plant Biol. 2006:8:831-40.

12. Taberlet P, Gieley L, Pautou G, Bouvet J. Universal primers for amplification of three non-coding regions of chloroplast DNA. Plant Syst Evol. 1991;170:97-106

13. Popp M, Oxelman B. Inferring the history of the polyploid Silene aegaea (Caryophyllaceae) using plastid and homoeologous nuclear DNA sequences. Mol Phylogenet Evol. 2001;20:474-81. 
14. Swofford DL. PAUP: phylogenetic analysis using parsimony (and other methods). Version 4.0. Slunderland: Sinnauer Associates Inc.; 2002.

15. Yang Z, Rannala B. Bayesian phylogenetic inference using DNA sequences: a Markov chain Monte Carlo method. Mol Biol Evol. 1997;14:717-24.

16. Huelsenbeck JP, Ronquist F, Nielsen R, Bollback JP. Bayesian inference of phylogeny and its impact on evolutionary biology. Science. 2001;294:2310-4.

17. Huelsenbeck JP, Ronquist F. MrBayes: Bayesian inference in phylogenetic trees. Bioinformatics. 2001;17:754-5.
18. Posada D, Crandall KA. Modeltest: testing the model of DNA substitution. Bioinformatics. 1998;1:817-8.

19. Thorogood C. The Malaysian Nepenthes: evolutionary and taxonomic perspectives. New York: Nova Science Publishers Inc.; 2010.

20. Kurata K, Jaffré T, Setoguchi H. Genetic diversity and geographical structure of the pitcher plant Nepenthes vieillardii in New Caledonia: a chloroplast DNA haplotype analysis. Am J Bot. 2008;95(12):1632-44.

21. Degtjareva GV, Casper SJ, Hellwig FH, Schmidt AR, Steiger J, Sokoloff DD. Morphology and nrlTS phylogeny of the genus Pinguicula L. (Lentibulariaceae), with special attention to embryo evolution. Plant Biol. 2006;8:778-90.

\section{Submit your next manuscript to BioMed Central and we will help you at every step:}

- We accept pre-submission inquiries

- Our selector tool helps you to find the most relevant journal

- We provide round the clock customer support

- Convenient online submission

- Thorough peer review

- Inclusion in PubMed and all major indexing services

- Maximum visibility for your research

Submit your manuscript at www.biomedcentral com/submit 